Abstracta Iranica

Revue bibliographique pour le domaine irano-aryen

Volume 42-43 | 2021

Comptes rendus des publications de 2019-2020

\title{
Rika Gyselen (éd.). Persia (552 BCE - 758 CE): Primary Sources, old and New
}

\section{Khodadad Rezakhani}

\section{(2) OpenEdition}

1 Journals

\section{Electronic version}

URL: https://journals.openedition.org/abstractairanica/53133

DOI: 10.4000/abstractairanica.53133

ISSN: 1961-960X

Publisher:

CNRS (UMR 7528 Mondes iraniens et indiens), Éditions de l'IFRI

\section{Electronic reference}

Khodadad Rezakhani, "Rika Gyselen (éd.). Persia (552 BCE - 758 CE): Primary Sources, Old and New", Abstracta Iranica [Online], Volume 42-43 | 2021, document 5, Online since 30 December 2021, connection on 22 December 2022. URL: http://journals.openedition.org/abstractairanica/53133 ; DOI: https://doi.org/10.4000/abstractairanica.53133

This text was automatically generated on 22 December 2022.

All rights reserved 


\title{
Rika Gyselen (éd.). Persia (552 BCE - 758 CE): Primary Sources, Old and New
}

\author{
Khodadad Rezakhani
}

\section{REFERENCES}

Rika Gyselen (éd.). Persia (552 BCE - 758 CE): Primary Sources, Old and New. Res Orientales XXVIII. Bures-sur-Yvette : Groupe pour l'Étude de la Civilisations du Moyen-Orient, $2020,216 \mathrm{p}$. + front and end matter

1 This volume of Res Orientales contains a section including five research articles, as well as a continuation of the publication of the Tabarestān Pahlavi archive. The first article by Parisa Ghasemi “Ghandejan/Dašt-e Bārin..." proposes to locate the medieval Islamic site of Ghadejān in the Sar Mašhad Plain in Western Fars and on the archaeological site of Kalīkūheh. The article by Rika Gyselen, "Pārs (224-421): les ateliers monétaires" considers the role of Pars as a place for coin workshops in the early Sasanian period, from Ardashir I to Yazdgerd I. In "Administrative Seal Impressions on Bullae Discovered on Tappe Bardnakoon," Khosrowzadeh, Norouzi, Gyselen, and Habibi write on the 22 administrative sealings discovered on an archaeological site in the Chaharmahal \& Bakhtiari province. Yousef Moradi and Almut Hintze's "A New Sealing of Pērōz from Takt-e Solaymān..." presents the fragment of a seal found in the site of Takht-e Solaymān and attributes it to the king of kings, Pērōz (459-484 CE) and contextualises it within a Zoroastrian ritualistic background. The last article by Rahim Shayegan, "Les Roi et son Interlocuteur" studies the compositional structure within the great Achaemenid Bisotoun inscription and the Sasanian inscriptions on Ka'aba-1 Zardušt and the Paikuli Monument, proposing that the Achaemenid narrative structures might have continued to influence the composition of inscriptions in the later periods. In the publication of the Tabarestān archive, Dieter Weber presents translations and philological studies of Tab. 11, 28, and 27 while Maria Macuch provides 
a juristic context for the documents which gives intricate information for legal procedures in the early post-Sasanian period.

\section{AUTHORS}

\section{KHODADAD REZAKHANI}

Leiden University 